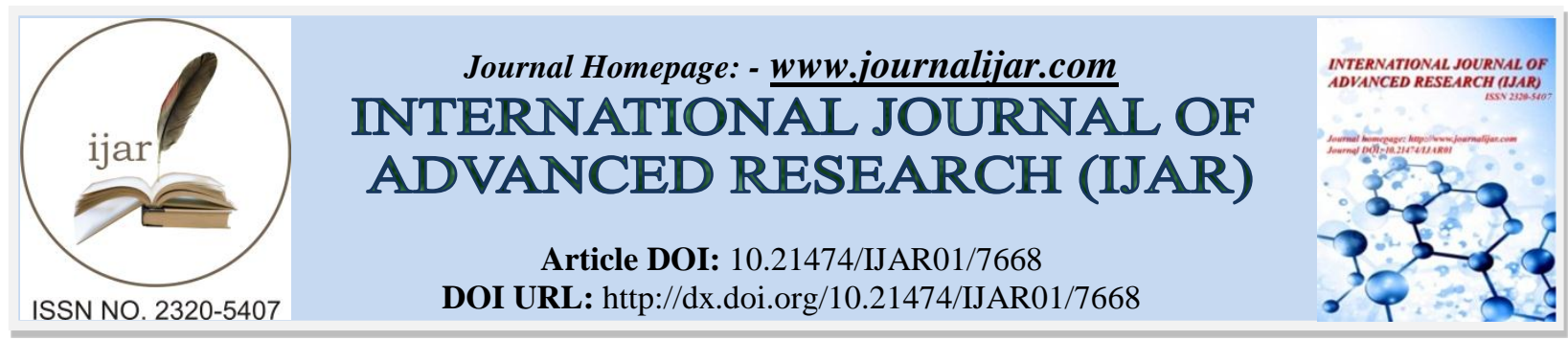

RESEARCH ARTICLE

\title{
THREAT TO SECULARISM- CONVERSIONS OR HOMECOMING.
}

\section{Dr. Rupam Jagota ${ }^{1}$ and Praisy Chanana ${ }^{2}$.}

1. Assist Professor, Department of Laws, GNDU Regional Campus, Ladhewali, Jalandhar.

2. Senior Manager Legal and Compliance in a MNC, [B.A., LL.B. (Hons.) FYIC, GNDU Regional Campus, Ladhewali, Jalandhar.

\section{Manuscript Info}

Manuscript History

Received: 05 July 2018

Final Accepted: 07 August 2018

Published: September 2018

Keywords:-

Secularism, Conversion, Homecoming,

Article 25 Constitution, Intolerance.

\section{Abstract}

The Constitution of India envisages India as a Sovereign Socialist Democratic Republic with emphasis on ensuring justice, liberty, equality and freedom. It is often visualized that India has been threatened by the invasion of diverse religious cultures which have disintegrated the secular character. The $42^{\text {nd }}$ amendment to the Constitution added the word "secular" and emphasized that state has no religion nor does it propagate any religion. Each individual has freedom of choice to practice profess, and propagate any religion and it has been granted by Article 25 of the Constitution of India. The conflict since between religions and people practicing the faith continue in an attempt to allure people from other faiths into one's own religion by convincing them, forcing them, to convert.

The moot/ core issue:

1. Weather conversion is valid, permissible within the purview of Article 25 of the Constitution of India

2. Weather conversion is anti- religious and amounts to excommunication from the society.

The researchers have analyzed Article 25 of the Constitution of India and its various implications to evolve few conclusions in support of the statement that everyone has Freedom of religion.

Copy Right, IJAR, 2018,. All rights reserved.

\section{Introduction:-}

"I swear by my religion, I will die for it. But it is my personal affair. The State has nothing to do with it. The State would look after your secular welfare, health, communications, foreign relations, currency and so on, but not your or my religion. That is everybody's personal concern!!"

Mahatma Gandhi:

Religion is the matter of faith with individuals and communities. It has its basis in a system of beliefs which are regarded by those who profess it as conducive to their spiritual wellbeing. Religion cannot be divorced from the modern political structure of the world. There has never been a word, more responsible in history, for causing such an amount of disruption in the society than 'Religion'. It's a hard reality that 67 years back two nations were born because of religious politics. The framers of the Constitution were aware of the dangers of religious arsenal in politics and made sufficient safeguards to ensure that the life of a nation marches ahead on a secular edifice. The Constitution stands on the bedrock of secularism though the term was nowhere used specifically in the original constitution. This ideal as faith has been expressed in the Indian Constitution via inclusion of the term "secular" in 
the Preamble through the $42^{\text {nd }}$ amendment made to it and the supportive articles which ensure freedom of religion to every citizen of India. India being a secular state professes it and it is the duty of every Indian to stand by and believe in this declaration. However, certain recent political events have once again questioned the relevancy, necessity and real meaning of this declaration.

\section{Secularism:-}

Secularism in India means equal treatment of all religions by the state. Unlike the western concept of secularism which envisions a separation of religion and state, concept of secularism in India envisions acceptance of religious laws as binding on the state, and equal participation of the state in different religions. The laws implicitly require the state and its institutions to recognize and accept all religions, enforce religious laws instead of parliamentary laws, and respect pluralism. India does not have an official state religion. The people of India have freedom of religion, and the state treats all individuals as equal citizens regardless of their religion. In matters of law in modern India, however, the applicable code of law is unequal, and India's personal laws - on matters such as marriage, divorce, inheritance, alimony - varies with an individual's religion.

India is one of the most diverse nations in terms of religion. Even though Hindus form close to 80 percent of the population, India enjoys multiple regions with majority populations of other religions particularly, Jammu and Kashmir with Muslim majority, Punjab with Sikh majority, Nagaland, Meghalaya and Mizoram with Christian majority ${ }^{1}$. The country has large Muslim, Sikh, Christian, Jain, Buddhists, Parsis and Zoroastrian population. Islam is the largest minority religion in India, and the Indian Muslims form the third largest Muslim population in the world, accounting for over 12 percent of the nation's population. To cherish this remarkable religious diversity and true spirit of secularism, Indian Constitution ensures to every citizen of India liberty to embrace any faith or religion of one's choice and propagate the same under Article 25.

\section{Fundamental Right: Freedom Of Religion:-}

Article 25. Freedom of conscience and free profession, practice and propagation of religion:-

1. Subject to public order, morality and health and to the other provisions of this Part, all prsons are equally entitled to freedom of conscience and the right freely to profess, practice and propagate religion ${ }^{2}$.

2. Nothing in this article shall affect the operation of any existing law or prevent the state from making any law-

3. Regulating or restricting any economic, financial, political or other secular activity which may be associated with religious practice;

4. Providing for social welfare and reform or the throwing open of hindu religious institutions of a public character to all classes and sections of Hindus.

Explanation I:-The wearing and carrying of kirpans shall be deemed to be included in the profession of the Sikh religion.

Explanation II:-In sub-clause (b) of clause (2), the reference to Hindus shall be construed as including a reference to persons professing the Sikh, Jain or Buddhist religion, and the reference to Hindu religious institutions shall be construed accordingly ${ }^{3}$.

A person has freedom to believe in the religious tenets of any sect or community. The right is not only to entertain such religious beliefs as may be approved by his judgment or conscience but also to exhibit his sentiments in overt acts as are enjoined by his religion. According to this Article, he may 'profess, practice and propagate his religion.

1. To profess a religion means the right to declare freely and openly one's faith.

2. The right to propagate one's religion means the right to communicate the person's beliefs to another person or to expose the tenets of that faith,

Right to propagate does not include the right to convert another person to the former's faith, because the latter is equally entitled to freedom of conscience. One may propagate freely his religious views for the edification of others. Article 18 of the Universal Declaration of Human Rights guarantees everyone the right to freedom of thought, conscience and religion which includes freedom to change religion and belief. The International Covenant on Civil and Political Rights, Declaration on Elimination based on religion or belief, American Convention of Human Rights

\footnotetext{
${ }^{1}$ Freedom of religion in India, Wikipedia, https://en.wikipedia.org/wiki/Freedom of religion in India

${ }^{2}$ M.P. Jain, Constitution of India, Universal Publication Private Ltd., New Delhi, $6^{\text {th }}$ Ed. Vol.2, 2014, p. 1785

${ }^{3}$ ibid
} 
Article 27(2) guarantees religious freedom is non dirigible (not capable of being suspended at any time) under any circumstances including war.

Conscious implies, a man's subjective sense of right or wrong. Thus, freedom of conscience would be meaningless unless it is supplemented by the freedom of unhampered expression of spiritual conviction in word and action. It implies no restriction of any kind can be imposed on man's inner thoughts, moral consciousness or his belief in God. Modes of worship considered by a religion to be its integral and essential part, are also secured. So everyone has a right to exhibit his or her belief in conduct, by such outward acts, as may appear proper in order to spread the ideas for the benefit of others. Therefore, every person is guaranteed the freedom to practice his religion- or to spread it if he so wishes - if that freedom is not abused to commit crimes or indulge in anti-social activities. Right to profess religion implies affirmation of one's belief, faith publically by words, gestures or conduct as he wills. Propagation means to spread one's religion by an exposition of its tenets. This means that if a person propagates his faith to another person and the person to whom the faith is propagated is convinced and wants to profess or practice it, he has the right to do so. If this is not allowed then the right to propagate religion guaranteed by the Constitution will be meaningless. Further, propagation as a means to convert is not necessarily based on ill will. Propagation has a close nexus with the term conversion and is seen as a corollary to propagation ${ }^{4}$.

\section{Debate On Conversion Or Homecoming:-}

Debate over the legitimacy of religious conversion in India has deep roots. Mahatma Gandhi, father of Indian independence, opposed proselytizing and people of one faith trying to convert others. But Ambedkar, born into a low Hindu caste whose members were treated as "untouchables", saw conversion as a means of social elevation and a way to revolt against the discrimination of the caste system. Ambedkar's 1956 conversion to Buddhism inspired about 3,65,000 erstwhile "untouchables" to follow suit". Jawaharlal Nehru, India's first post-independence prime minister argued that such a law would be a tool of harassment rather than protection, allowing police to intrude into intensely personal matters. Since the 1950s, certain Hindu groups have demanded for enactment of a national law to regulate religious conversions, which they argue is necessary to prevent the gullible from being coerced, duped or lured away from their ancestral faith.

Any attempt to impose a ban on all religious conversions would interfere with one's right to propagate one's religion under Article 25(1), apart from infringing the right to freedom of speech guaranteed under Article 19(1) of the Constitution. The Supreme Court has held that there is no fundamental right to convert another person to one's religion as such a right would infringe on the right to freedom of conscience guaranteed to all citizens of the country alike.

In this context, the Supreme Court in Rev Stainislaus vs State of M.P. ${ }^{6}$ has upheld the validity of the Acts passed by the Madhya Pradesh and Orissa Government, which prohibited forcible conversion from one religion to another in a manner reprehensible to the conscience of the community and which made conversions by force, fraudulence or allurement an offence ${ }^{7}$. The resultant position is that Article 25(1) of the Constitution does not guarantee the right to convert but only the right freely to profess, practice and propagate one's religion. Forcible conversion which is likely to give rise to an apprehension of breach of public order and which is reprehensible to the conscience of the community is not permissible under this Article.

The Article 25 of the Indian Constitution is a basic human rights guarantee that cannot be subverted or misinterpreted in any manner. It is in this context that the anti-conversion laws in India must be viewed. Anticonversion laws are promulgated on the premise that forced or induced conversions happen and need to be prevented. Such laws are controversial because they run the risk of being abused by communal forces that may have the tacit approval of the dominant political party in the state or country.

Forceful conversions are prohibited as the legislations specify, "No person shall convert or attempt to convert, either directly or indirectly, any person from one religion to another by use of force or by allurement or by any other

\footnotetext{
${ }^{4}$ M.A. Jawaid, Minorities of India: Problems and Prospects, Manak Publications Pvt Ltd., 2010, p. 300.

${ }^{5}$ Faizan Mustafa and Anurag Sharma, Conversion: Constitutional and Legal Implications, Kanishka Publishers, New Delhi, 2003, p. 7

${ }^{6}$ A.I.R. 1997 SC 908

7 Himachal, Gujarat, Madhya Pradesh, Rajasthan, Orissa, Arunachal Pradesh define 'forcible conversion' and 'force'
} 
fraudulent means, nor shall any person abet such conversions. Force has been defined in all acts as "to include show of force or threat of injury or threat off divine displeasure or social excommunication." 8 To prevent forcible conversions and reconversions eight states presented the freedom of religion bills and some have enacted it as law. These bills don't term anyone converting to Hindu from any religion as violation but termed as Homecoming. Some termed it as Anti-religion law.

These conversions or reconversions to religious faith are neither based on ideologies nor on deep understanding of religious fundamentals or principles but on Fear, allurements, inducements or vote bank politics. The conversions or homecomings, if made voluntarily, are permissible as fundamental right under article 25 of the constitution and cannot be held as anti-secular. These conversions might have certain basic and important impacts on political set up and circumstances. Intolerance issue re-emerged in the wake of religious fundamentalist challenging the social order of the society forcing people to look for alternatives or escape the country thereby threatening its integrity as a secular state.

India is an appropriate example of social, religious and cultural amalgamation. India is Ram and Ravaan as well. India is Gandhi and Godse too. India is Shiva and a prophet as well. India is an unexplainable, indefinable and incomprehensible nation, mixture and blend of all religions and numerous cultures with high degree of acceptance or tolerant power ${ }^{9}$. Today when religious bigotry has vitiated the environment, it is our prerogative to investigate how old is the idea of tolerance. India has strong traditions of cultic and religious syncretism and there is sufficient evidence to prove the prevalence of sectarian and religious antagonism from early times. Dayanand Saraswati believed in a religion based on universal values above all creeds but was opposed to all religions. His disciple Swami Vivekananda supported the vision that India alone is the land of toleration. Gandhi too considered Hinduism to be the most tolerant of all religions even though ardently supported communal harmony ${ }^{10}$.

Recently, the tolerance /intolerance as a virtue of India in the limelight of discussion. It has now become difficult to ascertain that what was the debate actually about?

Was it about the ruling Bharatiya Janata Party (BJP) leaders-and Hindu villagers - declaring that a 50-year-old Muslim lynched to death on suspicion of eating beef deserved it or Was it the Dadri tragedy, one of the worst communal crimes of the year? Or Was it about actor Aamir Khan-and other actors, mostly Muslim-being attacked (he defended himself here) for remarks on intolerance?

It can be easily ascertained that the soul/ core of the debate was religion, with fears of a religion or rather masses of a religion gaining majority in terms of number over the other religion and new realities for minorities, specifically Muslims. Another major contention was that Muslims would one day surpass Hindus in terms of their number or total population. There was a huge uproar and debate in the Lok Sabha during the winter session of the Parliament after a statement made by the Actor Aamir Khan in a popular forum that India has become an intolerant nation and not conducive to live.

However this fear or apprehension is not supported by data nor it is capable of threatening the core secular framework of the Constitution which harps on Secularism despite the disparities and advocates for freedom of all to ensure unity in diversity. The Home Minister of India Mr. Rajnath Singh addressing the Lok Sabha on 01/12/2015 too assured the House that the government will not spare anyone trying to disrupt social and religious harmony in the country.

Mr. Rajnath Singh wrapping up a two-day discussion in the House on intolerance by speaking about writers, artists and scientists who have returned their awards in protest over what they called growing acts of intolerance. He urged them to take back their awards and said: "Whenever the country has been in trouble, whenever adverse circumstances have emerged... it is the artists, teachers and scientists who have guided the country. If they think that circumstances like these are getting created... if you feel intolerance is increasing... please come, let us sit and talk. Please come, guide us."

\footnotetext{
${ }^{8}$ M.V.Pylee, Our Constitution, Government and Politics, Universal Law Publishing Co. Pvt. Ltd., 2002, p. 172

${ }^{9}$ Suhrith Parthasarathy, Conversion and freedom of religion, The Hindu, 23-12-2014

${ }^{10}$ B. Sivaramayya, Inequalities and The Law, Eastern Book Company, Lucknow 1994, p.2.
} 
He also said that: "We were, are and will be tolerant. Tolerance is in our veins... it's in our tradition, our culture... we are not tolerant under somebody's pressure... Mutthi bhar logon ke banaavati prachar se hamari chhavi par kalit nahin putegi (an artificial campaign by a handful cannot tarnish our image). "II

Freedom of religion enshrined in constitutional framework ensures equal recognition and acceptance of all faiths without discrimination. State advocates secularism therefore it ensures effective implementation of the fundamental right of religion to all. State has no religion therefore it neither advocates nor propagates any religion. It is purely the concern of the individual. State gives due recognition to every individual to profess and propagate religion as well as the freedom to convert to any faith if he is having a belief under fundamentals of new faith. However reasonable restrictions can be imposed if conversions are with an ulterior motive to take advantage of the benefits accessible under the personal laws of the new faith.

\section{Conversions Or Homecoming Are Not Anti Secular:-}

Conversions cannot be banned nor does the state exercising its power and interpreting the freedom and right to religion, make an attempt to stop them. The objective is to give a complete freedom of choice in professing and propagating ones religion. Conversion excludes use of force, threat, allurement, coercion. They are an open channel to an individual to retain the faith he is born into or to adopt a new faith which satisfies his mental and spiritual conscience. In the same belief homecoming is an acceptable perception within the meaning of freedom of religion.

"Hindus who, when young, had from pressure become Musalmans, were allowed to go back to the faith of their fathers. No man should be interfered with on account of his religion, and everyone should be allowed to change his religion, if he liked. ...People should not be molested, if they wished to build churches and prayer rooms, or idol temples, or fire temples."

Mughal Emperor Akbar, decreed the following in AH 1000 (1551-1552 CE)

\footnotetext{
${ }^{11}$ http://indianexpress.com/article/india/india-news-india/intolerance-debate-rajnath-draws-the-party-line-andsteps-across-it-as-well/ dated 02/12/2015
} 